\title{
A Comparative Study of Political Education in Chinese Universities and American Universities
}

\author{
Di Wang*, Risheng Zhong \\ Guangdong University of Foreign Studies, Guangzhou, China \\ Email: *sunny@gdufs.edu.cn
}

How to cite this paper: Wang, D. and Zhong, R.S. (2020) A Comparative Study of Political Education in Chinese Universities and American Universities. Open Access Library Journal, 7: e6973.

https://doi.org/10.4236/oalib.1106973

Received: November 9, 2020

Accepted: November 24, 2020

Published: November 27, 2020

Copyright $\odot 2020$ by author(s) and Open Access Library Inc.

This work is licensed under the Creative Commons Attribution International License (CC BY 4.0).

http://creativecommons.org/licenses/by/4.0/

\begin{abstract}
Political education determines the key issues of whom we train and whom we train for in universities. As a representative of developed capitalist countries, the United States conducts political education through civic education and other methods. This paper adopts a comparative study of political education in Chinese and American universities to discover the enlightenment of American political education to China.
\end{abstract}

\section{Subject Areas \\ Education}

\section{Keywords}

Chinese Universities, American Universities, Political Education

\section{Synopsis}

Political education is a vital content of ideological education in universities. It determines the key issues of whom we train and whom we train for in universities, which worth important research value. Various countries carry out explicit or implicit political education in universities in different forms to ensure that the high-end talents they train can serve the country's development. As the representative of developed capitalist countries and the largest economy in the world, the United States is not only very representative in terms of comprehensive strength and international influence, but also has a very complete system in terms of personnel training. Its political education is diverse, rich in content, and the impact is far-reaching and has important reference significance for the 
development of political education in Chinese universities.

\section{The Content of Political Education in Chinese and American Universities}

Political education is a comprehensive education practice of political ideology, morality and psychology of a certain class or political group in order to achieve its political goals and tasks. As shown in Table 1, In China, the main content of political education is Marxism-Leninism, Mao Zedong Thought, Deng Xiaoping Theory, the important thought of "Three Represents", the scientific outlook on development, Xi Jinping Thought on Socialism with Chinese Characteristics for a New Era, the Party's line, guidelines, policies and resolutions, etc., and content with ideal and belief education as the core and patriotism education as the focus. College political education courses are mainly public compulsory courses, including Deng Xiaoping Theory, Ideological and Moral Cultivation, Introduction to Mao Zedong Thought, and Marxist Political Economics. In the United States, there is no such name as political education. Civic education is the main form of political education in the US. However, they have carried out a large amount of substantive political education under the names of civic education, moral education, and legal education, which is "no name but real". Among these educations, moral education, legal education, religious education, and history education are all focused on political education in a certain aspect, while civic education is aimed at cultivating citizens with bourgeois democratic ideals and democratic behaviors. The content involved is quite widely. American civic education mainly includes patriotism education, moral quality education, legal education, rights and compulsory education, etc. It contains education on political outlook and education on civic religion. The education content of the $t$ countries is similar in many aspects, but China takes collectivist value as its core, while the United States takes individualist value as its core, which is the biggest difference between the countries [1].

Table 1. The content of political education in Chinese and American universities.

\begin{tabular}{|c|c|c|}
\hline & Chinese Universities & American Universities \\
\hline Core content & $\begin{array}{c}\text { The guiding ideology and theoretical } \\
\text { system of the CPC }\end{array}$ & $\begin{array}{l}\text { American Spirit and Civic education } \\
\text { with the supreme idea of American } \\
\text { democracy }\end{array}$ \\
\hline $\begin{array}{l}\text { Detailed } \\
\text { Content }\end{array}$ & $\begin{array}{l}\text { Marxism-Leninism, Mao Zedong Thought, } \\
\text { Deng Xiaoping Theory, Important Thought } \\
\text { of “Three Represents”, Scientific Outlook } \\
\text { on Development, Xi Jinping Thought on } \\
\text { Socialism with Chinese Characteristics for } \\
\text { a New Era, Party Lines, Guidelines, Policies } \\
\text { and Resolutions, Education of Ideals and } \\
\text { Beliefs, Education of Patriotism, etc. }\end{array}$ & $\begin{array}{l}\text { Patriotism education, moral quality } \\
\text { education, legal education, rights and } \\
\text { compulsory education, etc., education } \\
\text { that contains political views and } \\
\text { education of citizens' religion, } \\
\text { implemented through religious } \\
\text { education, moral education, legal } \\
\text { education, history education, etc. }\end{array}$ \\
\hline Core Value & Collectivist value & Individualistic value \\
\hline
\end{tabular}




\section{Tasks and Objectives of Political Education}

The fundamental task of political education in Chinese universities is to educate young students as well as to train socialist builders and successors with Marxism-Leninism, Mao Zedong Thought, Deng Xiaoping Theory, the important thought of the "Three Represents", the Scientific Outlook on Development, and Xi Jinping's Thoughts on Socialism with Chinese Characteristics in the New Era. The objectives of political education are to train generations of useful talents who support the leadership of the Communist Party of China and socialist system, and are determined to fight for life-long socialism with Chinese characteristics. This is also the goal of educational modernization. At the National Education Conference held in 2018, General Secretary Xi Jinping emphasized that universities must work hard to strengthen their ideals and beliefs in training students, educate and guide students to establish the lofty ideals of communism and the common ideal of socialism with Chinese characteristics, and strengthen students' path to socialism with Chinese characteristics, and to strengthen path self-confidence, theoretical self-confidence, institutional self-confidence, and cultural self-confidence, determined to shoulder the important task of national rejuvenation. Efforts should be made to cultivate patriotism, let the spirit of patriotism take root firmly in the hearts of students, educate and guide students to love and support the Communist Party of China, resolve to listen to and follow the party, take root in the people and contribute to the country. Efforts should be made to strengthen the cultivation of morality, educate and guide students to cultivate and practice the core values of socialism, steadfastly cultivate morality, and become a person with great love and great feelings.

American civic education emphasizes patriotism and loyalty, requires obedience to the laws of the society, and pays attention to citizens' responsibility and self-control in political life, and honesty in social relations. On the surface, civic education is intended to help citizens acquire the civic knowledge and civic skills necessary for their lives, so that they can become capable, knowledgeable, and responsible citizens in public life. Its essence is to cultivate citizens with bourgeois democratic ideals and democratic behaviors to achieve the political goals of a capitalist society. The political education of both countries has a distinctly political character [2].

\section{The Methods of Political Education}

China's political education has a long history and diverse forms. The ways and methods are very rich, mainly including model method, theory propaganda method, practice exercise method, self-education method, comparative identification method, counseling method, etc. The theory dissemination method is an important way of political education. Through the development of the party's advanced theory study and guidance, publicity and education, it helps students to deeply understand the party's guiding ideology and development philosophy. Understanding the party's development and growth is an inevitable choice in 
history. A model of advanced role model, develops the study of its deeds, points out the direction for students to work hard and learns an example. The practice exercise method examines their ideological status in practical activities to understand whether they have the ideological awareness and ability to listen to the party's command and serve the people [3].

In the context of changes in the world situation, complex international relations, deep-water reforms in China, and continued diversification of ideas, the difficulty of political education in Chinese universities also increases, and higher requirements have been placed on the professional quality of political educators in China. The methods of American political education are to inculcate capitalist values subtly through social sciences and civics courses, enlightening methods, on-site teaching methods, life guidance methods, reflective inquiry or critical thinking methods. For example, while imparting knowledge in courses on national history, religion, and law, they are also exporting the so-called American spirit and American values to allow citizens to recognize that the United States is an independent, democratic, and free country. American universities output American values through organizing students to participate in National Day and activities such as celebrations, visits to museums, and other practical activities to carry out on-site teaching. They make students believe that the national concept of the United States is also love and dedication, and is fully caring for the people through religious care for daily life and by conveying the concept of love and dedication. American civic education adheres to the humanist education philosophy, attaches great importance to personal development, pays attention to human value, human subjectivity and human dignity, and takes the individual development of the educated as the basis. This caters to the desire for personal development and is conducive to the logical development of civic education. Education in China focuses on positive guidance education, while the United States focuses on the subtle influence of combining classroom, practice, and life scenarios [4].

\section{Implementation Approach}

Political education in China uses ideological and political theory courses in colleges and universities as the main channel, and other philosophy and social science courses as auxiliary channels. At the same time, it promotes the construction of "curriculum ideological and political" content for all courses, that is, all courses must impart knowledge and give play to ideological politics. The educational function integrates political education into all aspects of students' professional learning and penetrates into all aspects of scientific research, teaching and social services [5]. As a powerful way to conduct political education in our country's universities, party and league organizations are an important platform for organizing students' political study, theoretical study and patriotism education. Social practice is seen as an effective way to help students better understand society. Students participate in voluntary services, grass-roots research 
to understand the social situation of the country. After going to the front line of poverty alleviation work in rural areas, students deeply feel the tremendous changes in the country's rapid development, the increase in people's income, and the growing sense of gain, and a deep understanding of the advanced nature of the socialist system. At the same time, in the development of campus cultural activities, the correct political outlook and value orientation are promoted to students through hidden courses, so that students can receive education unconsciously.

Political education channels in the US mainly include families, schools and mass media. Family education is the initial source of civic awareness and plays a fundamental role in political socialization. School education is the central institution for civic education, and public schools in the United States are the formal and main executive institutions for political education, which play a central role in education and conduct legal education and moral education for students from the beginning of children. Mass media is an effective means of disseminating national values. Through media dissemination, the political outlook and social values that the U.S. government wants to disseminate to the domestic people have been greatly improved. Good propaganda, as well as the government's so-called "democracy and emancipation concept" for countries around the world, has also been well propagated, and has left a deep political imprint in the minds of the people.

\section{Characteristics of Political Education in the United States}

\subsection{Complete Education System}

The American ideological education system is very complete and highly coherent. The educational system of universities inherits the educational philosophy of the middle school, connects the value expectation of society and the country, and plays the role of strengthening ideological education, connecting the inheritance and the national spirit, and enhancing the social identity. At the same time, ideological education in the United States covers social norms, political views, and religion. The content of education is specific and clear, and closely integrated with practice. It has an impact on the entire ideological field of students and enhances the effectiveness of ideological education.

\subsection{Infiltrate National Values through General Education, Focusing on Cultivating Citizens' Sense of Responsibility towards the Country}

Patriotism is the core content of American political education, which makes every American citizen proud of being an American. US President Kennedy said in his inauguration speech that "Don't ask what the country can do for you, ask yourself what you can do for the country" is a typical portrayal of American patriotism education. American patriotism education can be divided into $t$ parts: one is to enable citizens to understand the history, system, system, laws, and so- 
cial norms of the United States, and to accept and recognize them; the other is to emphasize civic responsibility, starting from the birth of a baby in the family, school and society through many aspects and channels, to publicize that citizens are responsible for the development of the family, society, and the country, which impels people actively participate in its construction.

American patriotism education is relatively successful. We can understand that American children take on housework and participate in family decision-making since they are young, and young people also participate in public welfare activities and social public affairs. These are ways and methods to cultivate a sense of civic responsibility. American students are generally more active and have a high degree of participation in school and social affairs. They believe that they can contribute to the development of the school, society and the country, and they are also responsible for fulfilling their civic obligations [6].

\subsection{Rich Education Content, Diversified Development Channels and Effective Hidden Courses}

Political education in American universities can be divided into explicit courses and hidden courses. Explicit courses are mainly planned and organized courses that directly publicize educational goals such as the American political system, constitution, and religion. Hidden courses refer to students acquire experience unconsciously in the school environment, including the layout of buildings, equipment, landscape and space in the school, the school's organizational system, knowledge selection, management evaluation, benefit distribution system, teacher-student relationship, peer relationship, school spirit, class style, teacher's behavior style, etc.

American schools often organize students to visit museums, courts, mayor's offices and other places, and conduct civic education in daily life through singing the national anthem and saluting the national flag; through festivals, cultural performances, and flag-raising ceremonies, instill allegiance to the country and Patriotism; use important events such as launching space shuttles and hosting the Olympics to promote the "American spirit"; strengthening public democratic awareness through election activities, enhancing people's support for the regime and the community and so on. It is through a variety of permeable and concealed education methods and methods that have enhanced the timeliness of ideological and political education and more effectively promoted the formation of good ideological and moral qualities of the people.

\section{Enlightenment of American Political Education to China}

\subsection{Improve the System Setting of Political Education}

Political education plays a directional role in personnel training, and determines the key issue of who we train and whom we train for. Political education influences the establishment of outlook on life and values, starting from the early childhood stage, and has long existed and played a role in the entire growth 
process of life. At different ages of people, the content and form of political education are different. Even in the early childhood stage, relevant education suitable for the younger age should be carried out to root the national spirit in the mind of children. The university stage is the key stage for the formation of human values, but education at this stage is based on the education of the youth stage. Without a good family atmosphere, country sentiment and national spirit as the foundation, it is impossible for the youth to establish a correct political outlook. The experiential education at the young age introduces the national spirit and national consciousness. During the young age, they learn about the national history and national system and mechanisms through ritual educational activities and related courses. During the young age, they strengthen the responsibility and mission of the country. The practical environment and atmosphere solidify social responsibility and the spirit of responsibility. A sound education system complements each other, supports each other, and is indispensable [7].

\subsection{Develop People-Oriented Determination of Educational Ideas and Methods}

During the past 40 years of China's reform and opening up, the country has undergone earth-shaking changes, and the people's living standards and education levels have been greatly improved. The young people who play an important role in society are those born in the $90 \mathrm{~s}$, and those born in the 00s will soon enter society. The new generation of young people grows up in an era of rich material and diverse information. They have a stronger self-awareness. Compared with the previous generation, they pay more attention to self-experience and feelings in their studies, life and work, Aimed at young people in the new era, political education should adjust the way of teaching, starting from their ability to accept and experience, taking their ideological puzzles at various stages of development as the starting point, and carrying out political education with their more acceptable language and expressions.

\subsection{Further Enrich the Forms and Methods of Political Education, and Gradually Develop from the Form of Offline Education to the Form of Education That Complements Each Other Offline and Online}

Political education is rich in the natural attributes of input values, so for young people and adults with strong self-awareness, more flexible education methods are needed. On the basis of positive education and curriculum education, it is a better way to appropriately increase implicit education. According to different situations and different objects, we must carefully study and select carriers, organize and design activities in a planned way, so that the educated can practice and cultivate their character while actively participating [8]. In recent years, the transition from "ideological and political courses" to "curriculum ideological and political" is a way to strengthen implicit political education. The breadth, depth and form of political education through courses have been further streng- 
thened, and the effect has been significantly improved. Combining the reception methods of young people in the new era, carry out more activities with participation and practice as the main content, such as watching important national conferences and activities, visiting museums, patriotic education bases, revolutionary sites, participating in the construction of a new socialist countryside, and conducting practical research. Activities such as studying the history of national development and the development of the party will have a huge impact on shaping the ideological and political consciousness of young people. At the same time, the in-depth application of the Internet has brought about tremendous changes in lifestyle and work styles. A considerable amount of learning and work content is completed online. Internet has a very large space for political education. At present, our online political education is still in its infancy. There is a very large online space for relevant educational guidance. In addition to online course education, the combination of political education and other online resources should be further expanded. It's suggested to develop more educational videos and games, add some content elements of political education to social software, and increase hidden political education content in different fields and categories online.

\section{Conclusion}

Political education is related to the direction of talent training in universities. Political education in Chinese and American universities have their own characteristics. Political education in Chinese universities is mainly based on explicit education such as courses and learning propaganda. Political education in American universities is infiltrating teaching, mainly hidden political education in life. Political education in the United States has the characteristics of a complete system, rich content, and diverse channels, and it attaches importance to the cultivation of citizens' national responsibilities. There is some enlightenment to China's political education. China can continue to strengthen political education in terms of improving the education system, strengthening the research on the ideological characteristics of young people in the new era, enriching the forms and methods of political education, and strengthening the multiple educational forms of offline and online interaction.

\section{Conflicts of Interest}

The authors declare no conflicts of interest regarding the publication of this paper.

\section{References}

[1] Chen, L. (2018) Comparative Ideological and Political Education. Renmin University Press, Beijing,

[2] Zhang, B. (2019) A Comparative Study on the Ideological and Political Education of Chinese and American College Students. Shenyang University of Technology, Shenyang. 
[3] Hayhoe, R. (1984) Contemporary Chinese Education. Sharpe, Armonk, New York.

[4] Deng, L. (2018) Research on American Skills Education Reform in the 21st Century. East China Normal University, Shanghai.

[5] Wang, Y. (2020) Practice and Reflection of School Ideological and Political Education with "Influence by Reasoning". Teaching and Management, No. 9, 36-38.

[6] Burton, R.C. (1983) The Higher Education Systems. University of California, Berkeley.

[7] He, D. (1998) Important Educational Documents of the People's Republic of China (1949 1997). Hainan Publishing House, Haikou, 207, 1344.

[8] Cao, Q. (2018) A Comparative Study of Ideological and Political Education between Chinese and American Universities. Journal of Henan University of Technology (Social Science Edition), No. 9, 119-124. 